\title{
'Oh, what words can do!': Rhetoric and the Moral Ambiguities of António Ferreira's Castro
}

(Forthcoming in Portuguese Studies, 33.1 (2017))

\begin{abstract}
The counsellors in António Ferreira's tragedy, Castro, have often been regarded as scheming and corrupt. This article argues, however, that their arguments echo debates around the virtues of severity and clemency found in Seneca's De clementia and many Renaissance treatises on kingship. In light of this, I demonstrate how two different, but equally valid, notions of what a ruler should do push against each other in the stichomythic battles of the play and show that key terms of moral evaluation end up in flux, thereby rendering the ethical decisions in Castro much more fraught. A renewed focus on rhetoric and on Renaissance treatises on kingship also enables a new view of Prince Pedro's character whose angry and uncontrolled speeches might have led early modern audiences to consider him the most wayward in the play.
\end{abstract}

KEYWORDS: António Ferreira, Castro, Portuguese drama, tragedy, clemency, rhetoric, ethics, De clementia, Seneca.

$* * *$

António Ferreira's verse tragedy, Castro (1598), is a play full of conflict: almost every character has a battle to fight, a fight to win. Yet, as Barthes said of Racine's tragedies, in Castro, too, 'parler, c'est faire'; the play's battles are waged in words, but no character can be sure that they have hador even heard - the final word. ${ }^{1}$ Characters invest in language to settle the meaning of actions and to determine which actions should be taken, but words betray those who wield them and slip out of their control. Rather than with bloodshed, Castro enthrals by sending our intellectual and emotional allegiances ricocheting between the characters, sometimes in unison, sometimes at divergent angles.

Castro draws on Portuguese history for its plot, telling the story of the judicial murder of Inês de Castro in 1355, the events leading up to this incident, and the beginnings of its catastrophic aftermath. Inês was a Galician noblewoman who accompanied her mistress, Constança of Castile, to the Portuguese court when the latter married the Prince Pedro, heir to the Portuguese throne, then occupied by his father Afonso IV. Despite the marriage, Pedro and Inês fell deeply in love. The Castilian influence of Inês and her brothers on the prince, however, perturbed the king and the Portuguese nobility. When Constança suddenly died in 1345, Pedro refused to take anyone but Inês as his wife, regardless of his father's wishes. The strength of their love and the political implications of the liaison (which had resulted in two children by this point) had Pedro's father, Afonso IV, increasingly worried and eventually his advisors declared that something drastic must be done to end the relationship. This is where the play begins. In Act I, Inês revels in her love affair, sharing her thoughts with her nurse, who is full of ominous foresight. The women leave the stage and the audience witness a fierce argument between Pedro and his secretary, who urges Pedro to end things with Inês. He refuses. The next act introduces us to King Afonso and his advisors, Pacheco and Coelho. Afonso's instinct is to be lenient with Inês, but his counsellors levy strong arguments in favour of killing Inês in order to safeguard the nation. In Act III Inês recounts a premonitory dream to the Ama just before the news of Afonso's decision reaches her. The following act features Inês confronting Afonso and his advisors. Inês's passionate speech in IV. ii. persuades Afonso and he

\footnotetext{
${ }^{1}$ Roland Barthes, Sur Racine (Paris: Seuil, 1960), p. 66.
} 
decides to let her go free. Her reprieve is short, however, as the counsellors urge Afonso to reconsider; he eventually leaves Inês's fate in their hands and they set out to kill her. In the final act, Pedro returns to the stage to hear the news of his lover's death and he declares vengeance on his father initiating the conflict that would, historically speaking, envelope the country in civil war.

The play was written during the 1550s whilst Ferreira was a student, and later lente [reader], at the University of Coimbra. ${ }^{2}$ At this time, the theme of dynastic crisis - embodied in the figure of Inês as a mother of Castilian lineage — must have struck a chord with the play's Portuguese audience. In 1554, prince João, heir to the Portuguese throne, died to widespread mourning. He was the ninth child of the unfortunate parents, D. João III and D. Catarina, to die and this series of misfortunes meant that the political climate in Portugal during the latter years of D. João III's reign were marked by despair and anxiety. ${ }^{3}$ Given the play's relevance to the political situation of its time, early readers/spectators likely sought out a moral lesson in it. Indeed, theoretical discussions about tragedy written and read in the period prescribed that drama should teach such a lesson by giving a moral portrait of a character to be emulated or avoided. ${ }^{4}$ Inês seems to have been that figure. Diogo Bernardes, for instance, a contemporary and friend of Ferreira's, suggests in a verse epistle to Ferreira that the play's heroine offers lessons on how to be Stoically constant in the face of disaster; lessons relevant to the need to remain calm and composed in the face of the tragedy and potential political turmoil resulting from so many royal deaths. ${ }^{5}$ Indeed, another play of the period, Diogo de Teive's Ioannes princeps (a tragedy written in 1554, printed in 1558, and precisely concerned with the death of the young Prince João), offers a vision of D. João III as a paragon of Stoic calm when confronted with the death of his son and heir. ${ }^{6}$

When considered as a whole, though, it is striking for a play that spends so much time talking about morality that a clear moral victor never emerges in Castro. Inês might be Stoic, but the key moral questions of the play are discussed in some scenes where Inês is not even present and the king, prince, and their advisors are the ones to thrash out many of the plays ethical quandaries. To draw out further the moral ambiguities of Castro, then, this essay re-examines the characters of Prince Pedro and the counsellors, Pacheco and Coelho, and reassesses critical judgements of their actions and arguments by paying particular attention to the relationship between rhetoric, ethics, and emotion. This study also adds to our understanding of Ferreira's play by identifying echoes of Seneca's influential treatise, De clementia, in Castro that have not been recognized to date.?

2 T. F. Earle, 'António Ferreira's Castro: Tragedy at the Cross-Roads', in Portuguese Humanism and the Republic of Letters, ed. by Maria Berbara and Karl A. E. Enenkel (Leiden: Brill, 2012), pp. 289-318 (pp. 289-90).

${ }^{3}$ Anthony Disney, A History of Portugal and the Portuguese Empire , 2 vols (Cambridge: Cambridge University Press, 2009), I, 172-3.

${ }^{4}$ See Catarina Fouto, 'The Reinvention of Classical Comedy and Tragedy in Portugal', in The Reinvention of Theatre in Sixteenth-Century Europe, ed. by T. F. Earle and Catarina Fouto (Oxford: Legenda, 2015), pp. 89-114 (p. 99).

${ }^{5}$ Carta II, 'Ao doutor António Ferreira', 11. 37-45 in Diogo Bernardes, O Lima, ed. by J. Cândido Martins (Porto: Caixotim, 2009).

${ }^{6}$ Nair de Nazaré Castro Soares, 'A Tragédia do Príncipe João (1554) de Diogo de Teive, primeiro dramaturgo neolatino português', in Teatro neolatino em Portugal no contexto da Europa: 450 anos de Diogo de Teive, ed. by Sebastião de Pinho (Coimbra: Imprensa da Universidade de Coimbra, 2006), pp. 183-214 (p. 213 n. 65). For an edition of the play with a translation into Portuguese, see: Diogo de Teive, Tragédia do príncipe João, ed. and trans. by Nair de Nazaré Castro Soares (Coimbra: Universidade de Coimbra, 1977).

${ }^{7}$ Several scholars have sought to identify the sources of Ferreira's play, and have pointed to other Senecan intertexts, but De Clementia has not been paid any attention to my knowledge. See: J. Wickersham Crawford, 'The Influence of Seneca's Tragedies on Ferreira's "Castro" and Bermúdez' "Nise Lastimosa" and "Nise laureada", Modern Philology, 12.3 (1914), 171-86; António Ferreira, La tragédie "Castro" d'António Ferreira, ed. by Adrien Roig (Paris: Centro Cultural Português, 1971); and Nair de Nazaré Castro Soares, 'A Castro à luz das suas fontes', Humanitas, 35-6 (1983-4), 271-348. 
Through an exploration of this Senecan intertext, I cast the debate between the King and his counsellors in Act II in a new light and argue that their stichomythic exchange dramatizes the clash of two equally legitimate moral schemes, rather than simply portraying the scheming of corrupt, Machiavellian advisors. Whilst stichomythia tends to be seen as little more than a stylistic feature that early modern authors inherited from their Classical forebears, I demonstrate that it provides Ferreira with a formal tool for exploring the political dilemmas of the historical events behind the play and for generating ethical doubts amongst his readers/audience. ${ }^{8}$ I argue that Ferreira stages the Renaissance the crisis of language and meaning in the stichomythic battles of the play: definitions of key terms for moral evaluation end up as 'stipulative description[s]', wriggling out of the semantic confines that characters attempt to set up. ${ }^{9}$

In addition to this reappraisal of stichomythia, a renewed focus on rhetoric in the play affords us insights into the mindset of the characters. Critics tend to go soft on Prince Pedro, but a close reading of the closing scenes of the play brings to light how terrifying Act $\mathrm{V}$ really is: Pedro transforms into an angry tyrant and this is displayed through his excessive and confused way of speaking. From the perspective of De clementia and other early modern treatises on kingship, Pedro's actions here are far from reasonable and thus, I suggest that Ferreira's contemporaries might have judged him the most harshly. This adds to the moral ambiguity of the play as, up to this point, the audience have probably been on his side because they have heard from Inês, the Chorus, Pedro himself, and even his father, Afonso, a series of arguments that explain Pedro's love affair with Inês, presenting his actions as understandable because they are those of a lover. Fear for what Pedro's threats in Act V portend tempers the sympathies that the audience has developed for him throughout the play and render him a more dubious figure at its close.

Before I turn my attention to Pedro in more detail, I shall zero in on one of the most misunderstood debates staged in the play: that between Pacheco, Coelho, and Afonso. Discussion of Pacheco and Coelho's arguments centre on the 'reason of state' argument put forward in II. i. (lines 696-700), where Pacheco and Coelho urge their King to consider the greater good and suggest that ends can justify means. ${ }^{10}$ Their arguments, however, also belong to a tradition that stretches back to ancient political philosophy; Seneca's De clementia, for example, argues that it is reasonable for kings to kill in the name of the common good. ${ }^{11}$ Traditionally, these characters have been seen, in the scathing words of John R. C. Martyn, as the 'sinister proponents of an unjust murder' ${ }^{12}$ In the chorus's words, they convince the king by the power of their words alone, a statement that plays into widespread fears about the power of counsellors should they turn to flatter their prince rather

\footnotetext{
${ }^{8}$ Soares points to Ferreira's skill at using stichomythia, but only goes so far as to say that it enlivens his text, 'A Castro', p. 290.

${ }^{9}$ Ian Maclean, Interpretation and Meaning in the Renaissance: The Case of Law (Cambridge: Cambridge University Press, 1992), p. 177.

${ }^{10}$ See António José Saraiva and Oscar Lopes, História da literatura portuguesa, 4th edn (Porto: Porto Editora, n.d.), pp. 291-2; and Martim de Albuquerque, Maquiavel e Portugal (Lisbon: Alêtheia, 2007), p. 52.

${ }^{11}$ De clementia in Seneca, Moral Essays, ed. and trans. by John W. Basore (London: Heinemann, 1970), I, 1.12.1 . Further citations are to this edition. For a discussion of the topic of 'reason of state' in the Renaissance, see Peter Burke, 'Tacitism, Scepticism, and Reason of State', in The Cambridge History of Political Thought 1450-1700, ed. by J. H. Burns and Mark Goldie (Cambridge: Cambridge University Press, 1991), pp. 477-98.

12 António Ferreira, The Tragedy of Ines de Castro, ed. and trans. by John R. C. Martyn (Coimbra: Universidade de Coimbra, 1987), p. 134.
} 
than give him true moral advice: 'Ah, quanto podem/ palavras, e razões em peito brando!' [What power/ Words and arguments have over a feeble heart!]. ${ }^{13}$

Nonetheless, ambiguities flicker in the chorus's moral judgements, as I will explore later in this essay. Indeed, as T. F. Earle has said, critics have often been unfair in assessing the advisors' moral character: the counsellors 'are not wicked, and are willing to take personal responsibility for their actions [...]. It is the political situation following Pedro's refusal in Act I to abandon Inês that makes it impossible for them to give any other advice. ${ }^{14}$ More than this, a closer inspection of the terms used to support the counsellor's arguments suggests that these characters construct a plausible case for the killing of Inês, one based on a moral scheme that stretches back at least as far as Seneca and which would have been familiar to Ferreira's audience. Once we begin to take their arguments seriously and explain their sources, then, the moral conundrums of the play appear even more insoluble.

Consider the following speech made by Pacheco in II. i, the first scene in which the counsellors try to persuade Afonso to kill Inês for the good of Portugal's continued sovereignty:

A clemência por certo é grã virtude, e dina mais dos reis que outras virtudes, polo perigo grande que há na ira em quem tão livremente assi a executa. Mas com esta o rigor é necessário, por não vir em desprezo tal virtude. Este é o que se chamou severidade, de que tantos exemplos nos deixaram os famosos romãos em paz, e guerra. Estas colunas ambas são tão fortes: que bemaventurado este teu reino, que nelas por ti só está tão fundado! De tal modo, senhor, hás-de usar delas, que ũa vá sempre d'outra acompanhada.

Exemplos tens mostrado de clemência.

Mostra agora, que é bem, severidade. (729-744)

[Certainly, clemency is a great virtue,/ More worthy of kings than other virtues,/ Because of the great peril inherent in anger/ In one who can gratify it so freely./ But as well as clemency, toughness is necessary,/ So that this virtue does not fall into contempt./ This is what has been called severity,/ Of which the famous Romans have left us/ So many examples in times of peace and war./ These two columns are so strong/ That your kingdom is truly fortunate/ To have been founded on them by you alone./ Sire, you should

\footnotetext{
13 'Castro' in António Ferreira, Poemas Lusitanos, ed. by T. F. Earle, 2nd edn (Lisbon: Fundação Calouste Gulbenkian, 2008), pp. 379-460, 11. 1504-5. The translation is from Ferreira, The Tragedy of Ines de Castro, IV. 3. 290-1. Further references to the play follow in the text and are from these editions and are included in the main text. For a discussion of early modern worries around the rhetorical power of counsellors, see Joanne Paul, 'The Best Counsellors are the Dead: Counsel and Shakespeare's Hamlet', Renaissance Studies, 30.5 (2016), 646-65 (pp. 650-2).
}

\footnotetext{
${ }^{14}$ T. F. Earle, 'António Ferreira, Castro', in A Companion to Portuguese Literature, ed. by T. F. Earle, Stephen
} Parkinson, and Cláudia Pazos Alonso (Woodbridge: Tamesis, 2009), pp. 68-71 (pp. 69-70). 
use them in such a way/ That one is always accompanied by the other./ You have given examples of clemency;/ Now show severity, for it is right to do so.] (II. i. 131-50) ${ }^{15}$

Without proper contextualization, it can seem as though the counsellors warp the language of virtue by a very crooked logic indeed. The 'harshness', 'toughness', and 'severity' that they prescribe, however, form not euphemistic packaging for evil intentions, but rather pertain to the virtue of severitas [strictness]. The argument made here finds parallels in various ancient and Renaissance treatises on kingship that considered strictness a virtue that rulers needed to show on particular occasions. Although the allusions are somewhat indirect, one can see elements of Seneca's De clementia in Pacheco's speech, as he tries to demonstrate that both clemency and strictness are virtues for a king, citing 'the famous Romans' as his example for the need to demonstrate both leniency and rigour, as the situation demands. In this way, he makes Afonso aware that cruelty and strictness are quite different, as Seneca also does: 'The ill-informed think that its [i.e. clemency's] opposite is strictness; but no virtue is the opposite of a virtue. What then is set over against mercy? It is cruelty, which is nothing else than harshness of mind in exacting punishment' (De clementia, II. 4. 1). De clementia became something of a reference work in early modern political thought, filtering into many treatises and manuals on how best to rule. ${ }^{16}$ As a Humanist poet educated at the University of Coimbra, Ferreira in all likelihood knew Seneca's moral essay and possibly read it in the complete works compiled by Erasmus, of which there are several copies in Portuguese libraries. ${ }^{17}$ But it is not necessary to find a direct citation of Seneca's essay in the play to be able to argue that Pacheco's argument had legitimacy at the time. Cicero advocated severitas as a suitable course of action in his letters to Brutus where he recommends that strictness was required to put a stop to the civil wars. ${ }^{18}$ Petrarch also suggests, in a text with both Senecan and Ciceronian inflections, that too much leniency could end up being very cruel. ${ }^{19}$ The Humanist, Jerónimo Osório also cites in his De nobilitate (first published in 1542) a number of biblical figures (including Moses and Christ himself) who succeed in blending kindness with strictness. ${ }^{20}$

That is not to say that strictness was always preferred to clemency. In Seneca's eyes, pity and cruelty were the vicious extremes of the virtues of clemency and strictness respectively; excessive clemency would devolve into pity (a vice) and excessive strictness into cruelty (also a vice). Indeed, as Afonso says in line 1462, Seneca suggests that it is better to err on the side of clemency, because cruelty (as the extreme form of strictness) has more destructive consequences

\footnotetext{
15 The translation has been slightly altered here because Martyn translates 'aspereza', 'rigor' and 'severidade' all as 'severity'.

${ }^{16}$ For a discussion of how extensive the influence of this essay was in early modern Europe, see Peter Stacey, Roman Monarchy and the Renaissance Prince (Cambridge: Cambridge University Press, 2007), p. 208.

${ }^{17}$ For a general discussion of the dissemination of Erasmus's printed works in Portugal during the sixteenth century, see Catarina Barceló Fouto, 'Diogo de Teive's Institutio Sebastiani Primi and the Reception of Erasmus' Works in Portugal', in Portuguese Humanism and the Republic of Letters, ed. by Maria Berbara and Karl A. E. Enenkel (Leiden: Brill, 2012), 128-49.

${ }^{18}$ For examples, see To Brutus in Marcus Tulius Cicero, The Letters to His Friends, ed. by W. Glynn Williams (Cambridge, MA: Harvard University Press, 1954), III, pp. 615-738 (I. 2a. 2 and II. 5. 5). See also Melissa Barden Dowling, Clemency and Cruelty in the Roman World (Ann Arbor: University of Michigan Press, 2006), pp. 34-7.

19 See Stacey, p. 155.

${ }^{20}$ Jerónimo Osório, Tratados da nobreza civil e cristã, trans. by A. Guimarães Pinto (Lisbon: Imprensa Nacional Casa da Moeda, 1976), pp. 209-10.
} 
(De clementia II. 4. 4.). ${ }^{21}$ These ideas were certainly circulating in Ferreira's time as Diogo de Teive shares a similar opinion in one of his sententiae addressed to the young D. Sebastião in Epodon siue Ia[m]bicorum carminum libri tres (first printed in 1565 with parallel Latin and Portuguese text): 'Severidade muito poucas vezes/ Se louva ou se busca ou se deseja,/ Quasi sempre a clemência é desejada' [Severity is rarely praised or sought out or desired; it is clemency that is always desired]. ${ }^{22}$

What the counsellors propose, then, coheres with modi operandi that various Classical and early modern theorists deem virtuous. Though many writers would side with Teive and Seneca himself when it comes to clementia and severitas, there was no single viewpoint on kingly behaviour that was universally accepted, as is shown by the numerous examples of texts that cite severitas as a necessary virtue in a ruler. Unlike critics such as Martyn, I think that Ferreira did not intend to make the audience side only with Afonso, but to stop and think whether - under the extremely difficult circumstances of the play - the actions promoted by the counsellors could be seen as valid.

This clash between clemency and strictness sends shockwaves through the terms of ethical evaluation deployed in the play, dislodging them from solid, unambiguous meanings. What is - or is not - 'just' becomes dependent upon the moral scheme to which one subscribes. In order to explore this in more detail, let us turn to one of the tensest moments of the play (IV. ii.) when Pacheco and Coelho fight to change the King's mind after Inês has talked him round in the preceding scene:

Rei: Não vejo culpa que mereça pena.

Pacheco: Inda hoje a viste. Quem ta esconde agora?

Rei: Mais quero perdoar que ser injusto.

Coelho: Injusto é quem perdoa a pena justa.

Rei: Peque antes ness'estremo que em crueza.

Coelho: Não se consente o rei pecar em nada.

Rei: Sou homem.

Coelho: Porém rei.

Rei: O rei perdoa.

Pacheco: Nem sempre perdoar é piadade. (1458-65)

[King: I do not see a fault which deserves punishment. Pacheco: You saw it only today; what hides from you now? King: I prefer pardon to injustice. Coelho: Unjust is he who does not inflict a just penalty. King: Rather might I sin in this excess, than in cruelty. Coelho: A King is not allowed to sin at all. King: I am human. Coelho: But a King. King: A King pardons. Pacheco: The pardon is not always merciful] (IV. ii. 244-51)

Here, Ferreira exploits the dramatic potential of stichomythia to the fullest, demonstrating the stalemate between two lines of moral thinking. In stichomythia, where speakers alternate in quick succession, the flow of the dialogue depends upon each speaker picking up where another left off. Speakers thus appropriate the language of their interlocutor and 'aggressively wrap' this in their own worldview. ${ }^{23}$ This hostile takeover of another person's words renders this dialogue fraught and

\footnotetext{
${ }^{21}$ The possibility of lapsing into vice is possible because pity and cruelty are close to clemency and strictness, see: $D e$ clementia, II. 4. 4).

22 Diogo de Teive, Obra completa, ed. and trans. António Guimarães Pinto (Lisbon: Esfera do Caos, 2012), p. 827.

${ }^{23}$ Simon Goldhill, Sophocles and the Language of Tragedy (New York: Oxford University Press, 2012), p. 51.
} 
uncomfortable because neither side is able to settle the use and meaning of the words they use: the concepts one speaker uses to promote their own ideas are wielded, in turn, against them. The tension builds as two different moral frameworks push against each other: one in which it is better to be too clement than to risk being unjust and another that sees granting pardons too easily as the route to injustice.

A dimension of Ferreira's play that is often neglected, because of the scanty information available about the performance history of the play, is how a scene like the one cited above would be staged. When asked about this issue, undergraduate students are remarkable in the consistency of their imagination: they have Pacheco and Coelho hounding Afonso on stage, stalking him as he tries to get away from their crafty replies. In other words, they bring their ideas about staging in line with conventional views of the two counsellors, suggesting they are snarling Machiavels in advisor's clothing. But the debate is a deadlock, as neither side manages to bring the other round to their way of thinking. The counsellors seek the assent of their king for their proposed actions and do not assume the power simply to compel their king to act in the way they see fit, they challenge the king, as good counsellors should, but are waiting for the king's permission ('licença', 1501) before they act. Indeed, the discussion continues for another thirty lines after the passage cited above, suggesting that the argument is one not easily won. If we see the advisors as acting with some moral legitimacy in the play, it would be preferable to see this scene as a series series of verbal lunges, parries, and ripostes, where king and counsellors both hold their own and face each other down without giving ground on the stage. Viewing this as a scene of aggression, then, derives from the harsh judgements of the counsellors made by critics and students who have not recognized the moral validity of their arguments and the fact that they had currency and weight in the period. The challenge for a director who wants to embrace the true ambivalence of the play is to make Pacheco and Coelho appear less wicked than students sometimes imagine them to be, affording their words the moral authority that they might once have possessed and which renders Afonso's decision all the more impossible.

The fact that the arguments on both sides of the debate have recourse to the same evaluative terms unsettles the meaning of key words in the play. A verbal tug of war ensues where both sides try to get the firmer grip on a word like justice (justiça) and drag it in the direction they want. The same is true of another morally evaluative term, central to De clementia and to medieval and early modern political theory at large: cruelty. When someone hurls the word 'crueza' [cruelty] — or its related words 'cruel' [cruel], 'cru(a)' [cruel], 'crueldade' [cruelty], 'cruamente'/'cruelmente' [cruelly] — at someone else, they challenge a ruler's moral (and political) authority. ${ }^{24}$ But the play shows that - at least in theory - one person's cruelty can be another person's justice, as Pacheco states:

Se te parece em parte isto crueza, não é crueza aquela, mas justiça, quando de cruel ânimo não nasce. (722-4)

[If to you there seems to be some cruelty in this,/ It is not at all an act of cruelty, but of justice,/ For it does not stem from a cruel heart] (II. i. 128-30)

Here, as elsewhere, we see the characters in Castro wage a battle of words over what they should or should not - deem cruel; in other words, over who has the moral high ground. 'Crueza' [cruelty] and its related noun, adjectives, and adverbs appear sixty-seven times in the play and are shot at

24 Daniel Baraz, Medieval Cruelty (Ithaca: Cornell University Press, 2003), pp. 10, 88, 124. 
particular actions as a rhetorical way of delegitimizing them: no one wants to be called cruel and, therefore, to be placed in a long line of tyrannical figures from myth and history.

It is Inês and her ally, the Chorus, who use these words most frequently. In Inês's plea for mercy in IV. i., cruelty becomes a critical term in dissuading Afonso from acting the way he intends. It is important, though, to recognize that the chorus is not a disinterested party in the events of the play; when they intervene in the action of the play, they usually support Inês, rather than acting as an impartial 'voice of reason'. ${ }^{25}$ In IV. i., for instance, Inês calls the chorus her 'friends' (1222) and asks them to assist her in asking for mercy from the Afonso (1224).

Once Inês has been killed, the chorus becomes Inês's principal champion, though their attribution of cruelty to Afonso's actions does not remain uncontested:

Coro: Enfim venceu a ira, cruel imiga de todo bom conselho. Ah, quanto podem palavras, e razões em peito brando!

Eu vejo teu esprito combatido de mil ondas, ó Rei. Bom é teu zelo; o conselho leal; cruel a obra.

Rei: Por crueza julgais o que é justiça?

Coro: Crueza a chamará tod'outra idade.

Rei: Minh'alma inocente é, conselho sigo. (1503-11)

[Chorus: Finally anger has triumphed, cruel enemy/ Of all good counsel. Ah! What power/ Words and argument have over a feeble heart!/ I see your spirit tossed/ On a thousand waves, O King. Your zeal is good;/ Your counsel, loyal; your action, cruel. King: You judge as cruel what is just? Chorus: Posterity will call it cruelty. King: My soul is innocent; I have followed counsel.] (IV. iii. 289-97, translation modified)

J. Wickersham Crawford dismisses line 1509 as a weak defence against the chorus's accusations and considers it further evidence of the King's hopeless vacillating in the play as a whole, because Afonso soon after changes his attitude from defensiveness to regret. ${ }^{26}$ In contrast, I think that these lines show Ferreira's staging of the difficulty of moral judgement. Part of the ambiguity of Castro is the way in which words can be used (with equal legitimacy) for startlingly different purposes. As Quentin Skinner and Michael Moriarty have argued, vices and virtues could, in the early modern period, be dressed up in language to look remarkably like one another, causing a great deal of moral anxiety. ${ }^{27}$ In Portuguese literature, one only has to look at the velho de Restelo in Os Lusíadas for the way in which events can be re-described in surprising ways. For the old man of Restelo, fame is a euphemistic paradiastole of greed, the real motivation behind the Portuguese voyages to India. ${ }^{28}$ Here, in Castro, the verbs 'julgar' and 'chamar' draw attention to game of re-description at play: actions are 'judged' or 'named' cruel rather than being inherently so.

\footnotetext{
${ }^{25}$ For further discussion of the Chorus and especially the ambiguous odes that close four of the play's five acts, see Earle, 'Tragedy at the Cross-Roads', pp. 297-309.

${ }^{26}$ Crawford, p. 179.

${ }^{27}$ Quentin Skinner, Visions of Politics (Cambridge: Cambridge University Press, 2002); Michael Moriarty, Disguised Vices (Oxford: Oxford University Press, 2011).

${ }^{28}$ For a discussion of paradiastole in Camões's epic, see Hélio J. S. Alves, Camões, Corte-Real e o sistema da epopeia quinhentista (Coimbra: Universidade de Coimbra 2001), pp. 513-23.
} 
To add to the moral complexities of the play, the chorus's denouncements of Pacheco, Coelho, and Afonso come with equivocations. In the chorus's lines cited above, they suggest that anger prevails, threatening 'bom conselho' [good counsel], yet then assert that the advice given was 'leal' [loyal]: a positive judgement of it, as loyalty was the most important quality in a counsellor. ${ }^{29}$ Manuals about how to behave as a king all warned against self-interested advisors more focussed on winning favour for themselves than on helping their prince make good decisions. ${ }^{30}$ Pacheco and Coelho do not pursue their own ambitions, but aim to secure Portugal from the threat of loss of independence represented by Inês and her connections to Castile. It is in this way that their advice can be called 'loyal' and, ultimately, good. The description of their advice as 'leal' seems at odds with other moments when the chorus is very clear about its condemnation of Pacheco and Coelho (e.g. 1096-100). I think, though, it is important to keep both the positive and the negative in mind. Ferreira valued the counsel of friends or royal advisors as a necessary part of toeing a moral line in life. His poems are populated by figures who need advice and those who give it. Indeed, in the passage above, Afonso defends himself against the charges of the chorus by referring to the fact that he follows advice: 'Minh'alma inocente é, conselho sigo' (1511) [My soul is innocent; I have followed counsel (IV. iii. 297)]. In other words, advice is what is supposed to save him. Were it not for the Chorus and the actions of Pedro at the end of the play, we might even think that Afonso took a tragic, but justifiable decision.

In Ferreira's eyes, poets and kings require counsellors to assure their moral wellbeing, especially in trying situations. In his other works, Ferreira suggest that he has his friends, like Manuel de Sampaio, to reel him in and that kings have their advisors and humanist poets, such as Ferreira himself, to offer them the advice they need to rule virtuously. ${ }^{31}$ It would thus be strange to think that in Castro Ferreira would want to make counsellors come across as the bad guys. In light of the moral basis for the counsellors' arguments, the Chorus's half-praise for them, and the view of advisors propagated in Ferreira's wider work, we should not be too heavy-handed with our treatment of these characters, because, in spite of their persistence, it is clear that they do allow Afonso to make the final call. Plenty of good advice is given in Ferreira's tragedy: problems arise more frequently when characters do not listen to it. The Ama, for example, gives good Stoic advice to Inês. One might even say that it is because of her that such an amazing transformation takes place during the play, as Inês changes from love-struck lady into Stoic heroine. The Secretário also explicitly declares himself Pedro's adviser, there to temper his anger and to keep the impetuous prince in check (see: 282-7).

If his father sees himself trapped between his fears of being cruel and a compulsion to follow the advice he has been given, weak because he could not make up his mind (773-7), Pedro completely ignores his wise advisor. In the case of Pacheco and Coelho there is some doubt as to whether their advice should have been followed, but there is little doubt that the Secretário has a point in I. iii when he tells Pedro to quell his anger. From the perspective of the speculum principis tradition, Pedro emerges as particularly morally wayward — worse perhaps than his father because he refuses to listen to advice at all:

Ifante: Sigue minha razão, minha vontade.

Secretário: Não te vejo razão, vejo vontade.

\footnotetext{
${ }^{29}$ See also 11. 1514-6 where the Chorus, too, fail to extract a moral lesson from the play's events.

${ }^{30}$ See, for example, Jerónimo Osório Da instituição real e sua disciplina, trans. by António Jotta da Cruz Figueiredo (Lisboa: Pro Domo, 1944), pp. 125, 400; Desiderius Erasmus, The Education of a Christian Prince, ed. by Lester Kruger Born (New York: Norton, 1968), pp. 193-4.

${ }^{31}$ See Ode I. 4 and 7, and Cartas II. 1 and 2 in Ferreira's Poemas Lusitanos.
} 
Ifante: Sigue a vontade, que forçar não podes.

Secretário: Manda-me o que te devo que a não siga.

Ifante: Queres mandar teu príncipe?

Secretário: Mas sirvo.

Ifante: Obedece ao que quero.

Secretário: Manda o justo. (408-13)

[Pedro: Follow my reason, my desire. Secretary: In you I see no reason, but just desire. Pedro: Follow that desire, against which you can do nothing. Secretary: My duty to you commands me not to follow this desire. Pedro: Do [you] want to command your Prince? Secretary: Rather, serve him. Pedro: Be obedient to my wishes. Secretary: Order what is just.] (I. iii. 408-13)

Words relating to power and ruling crowd these lines ('vontade', 'servir', 'mandar', 'forçar', 'obedecer', 'poder' [desire, to serve, to order, to force, to obey, to be able]). Once again, however, the characters contest the definition of key terms. The Secretário challenges what Pedro understands by ordering and serving: he makes it clear that should the prince not order what is right, serving him would not mean doing his bidding, but disobeying him. This echoes a long line of political thinkers who argued that a ruler could rightfully be deposed if they overstepped the mark and descended into cruelty; a viewpoint re-iterated by contemporaries of Ferreira, such as Camões. ${ }^{32}$ The Secretário also confronts how Pedro conflates 'razão' [reason] with 'vontade' [desire] in the opening line of this passage. The syntax of line 408 suggests a certain synonymity between 'razão' and 'vontade' by the repetition of 'minha' [my] and the absence of a conjunction. This is possible because both 'reason' and 'will' have to do with orders: 'razão' refers to Pedro's reasoning (i.e. what he has decided to do) and 'vontade' more straightforwardly to his wishes. The Secretário, however, disturbs the suggested relationship between these two words by implying that he sees only one in Pedro's behaviour. He thus highlights the difference in the semantic range of the two words; namely, the associations of 'reason' with rational thought and 'desire' with irrational, emotional thinking. There is a proleptic dimension to this passage too, as it signals that Pedro has some tyrannical character traits: he lacks reason and wishes to subjugate everyone to his will. ${ }^{33}$ Indeed, earlier even Pedro himself points to his hot-headedness, saying that his anger is growing against those who challenge him and indicating that it is the Secretário who can (and must) calm him down (203-4).

All this suggests that Pedro has some worrying characteristics, which erupt in Act V when he transforms into a furious, Senecan tyrant. ${ }^{34}$ This early scene between the secretary and Pedro gives us an indication of how his anger will ignite civil war in Portugal after Inês's death. Interestingly, the counsellors and Afonso are also accused of being overcome by anger. But when we compare their behaviour with that of Pedro, there is little comparison to be made. Pacheco, Coelho, and Afonso speak in a measured way and they put forward careful (and justifiable) arguments.

As I have explored, for the majority of the play, the chorus, Inês, Pacheco, Coelho, and the King make concerted efforts to lift the label of 'cruel' from their actions or affix it to the course of action promoted by another character. It is startling, then, that, at the end of the play, Pedro claims cruelty for himself:

\footnotetext{
${ }^{32}$ Clive Willis explores this tradition in relation to Os Lusíadas in his Camões: Prince of Poets (Bristol: HiPLAM, 2010), pp. 132-4.

${ }^{33}$ For the fact that savagery and cruelty distinguish the tyrant from the king, see De clementia I. 12. 1.

${ }^{34}$ Earle, 'Tragedy at the Cross-Roads', p. 291.
} 
Mas eu me matarei mais cruelmente do que te a ti mataram, se não vingo com novas crueldades tua morte. (1750-2)

[But I promise to kill myself more cruelly/ Than they killed you, if I do not avenge/ Your death my new cruelties.] (V. ii. 148-50)

Beyond what he says, Pedro's rhetoric in Act V bears the mark of anger. As Peter Stacey has argued, 'tyrants have a distinctive rhetoric: their lack of ratio is manifested in their oratio' ${ }^{35} \mathrm{We}$ can detect Pedro's unreasoned, tyrannical thinking, then, in the way he speaks. Indeed, rhetorical manuals of the period emphasize the need for rhetorical tropes to match the emotional state of the speaker. For example, Cypriano Soarez, a Spanish rhetorician who taught and printed his work in Portugal, suggests in his De arte rhetorica (1562): 'when brutality, hatred, and pity are the weapons of debate, who will endure a speaker who expresses his anger, sorrow, or entreaties in figures of antithesis, in balanced cadences, and in correspondences in word terminations? ${ }^{36}$ As much as rhetoric is a way of writing, then, it can be also used as a way of reading: rhetorical analysis can expose the emotions a writer intended a character to display. In Pedro's case, this kind of diagnosis by rhetorical analysis proves illuminating especially when we contrast the way Pedro speaks to the manners of speaking of the other characters in Castro. Pedro's speech once he hears the news of Inês's death is rhetorically excessive; exclamations and rhetorical questions abound, suggesting that Pedro does not know what to do as grief takes over: ${ }^{37}$

Que direi? Que farei? Que clamarei?

Ó fortuna! Ó crueza! Ó mal tamanho!

Ó minha Dona Inês, ó alma minha, morta m'és tu? Morte houve tão ousada

que contra ti podesse? Ouço-o, e vivo?

Eu vivo, e tu és morta? Ó morte crua!

$[\ldots]$

Ah, minha Dona Inês, ah, ah, minha alma! (1673-8, 1684)

[What shall I say? What shall I do? What shall I cry?/ Oh, fortune! Oh, cruelty! Oh, terrible evil!/ Oh, my Lady Ines, Oh my soul,/ Are you dead? Was death bold enough to exercise/ Its power against you? Do I hear this, and live?/ How am I alive if you are dead? O cruel death!/[...] Ah! My Lady Ines! Ah, ah! You, my soul!] (v. ii. 71-5, 82)

The density of devices typically used to evoke intense emotions suggests that his reason has fully evaporated. In the rhetorical treatise, Ad Herennium, the figure of exclamatio (apostrophe) is connected with grief and indignation, both of which are at play here. ${ }^{38}$ By line 1684 his speech

\footnotetext{
35 Stacey, p. 60.

${ }^{36}$ Lawrence J. Flynn, The 'De Arte Rhetorica'(1568) by Cyprian Soarez: A Translation with Introduction and Notes (unpublished $\mathrm{PhD}$ dissertation, University of Florida, 1955), p. 334.

${ }^{37}$ For a list of the tropes of anger, see Juvenal, Satires: Book 1, ed. by Susanna Morton Braund (Cambridge: Cambridge University Press, 1996), p. 18.

${ }^{38}$ Rhetorica ad Herrennium, ed. and trans. by Harry Caplan (London: Heinemann, 1954), IV. 15. 22.
} 
descends into a slew of exclamations: the syntax breaks down like his reason. Anger then slowly comes to replace grief and Pedro transforms into a tyrant who delights in gore:

Abra eu com minhas mãos aqueles peitos.

Arranque deles uns corações feros, que tal crueza ousaram. (1754-6)

[May I be able to open their chests with my hands,/ May I be able to tear out such cruel hearts/ Which dared commit such a cruelty] (V. ii. 152-4)

Pedro's irrationality is brought further into relief by the Stoic words of the Messageiro, who attempts to get Pedro to control his grief and to occupy himself with what is his duty:

Senhor, pera chorar fica assaz tempo.

Mas lágrimas que fazem contr'a morte?

Vai ver aquele corpo, vai fazer-lhe

as honras que lhe deves. (1714-7)

[Sire, enough time remains for weeping,/ But what power do tears have against death?/

Go and see this body, go and render to it/ The honours which you owe to her.] (v. ii.

$112-5)$

The intervention of the messenger suggests that a more controlled response is possible, highlighting that Pedro is lost to reason. This also might remind readers of the Teive's play Ioannes princeps where the King's stoic response to calamity is praised by Eubularchus and Philanax in Act V. Pedro is certainly not the same kind of character.

Ferreira insists on the King as the head of the body politic (715-16) and this is why Afonso's vacillations are so worrying: a king should not dither, but be constant and resolute, otherwise, like Agamemnon, he becomes unfit for his responsibilities. ${ }^{39}$ It is also because of the king's status as the head of the country's political body that anger is particularly dangerous in Pedro and Afonso. As Peter Stacey says, 'the res publica risks losing its mind if the ruler loses his temper' ${ }^{40}$

A reader well-versed in Seneca's moral ideas and in the 'mirror for princes' genre might well view Pedro particularly harshly, then, because anger is viewed in these treatises as the foulest of all passions: his judgement clouded in a hot-blooded haze, the angry prince is unable to act according to the Stoic precepts that should guide him and thrusts himself and his state into jeopardy. Seneca is clear about this when he declares 'cruel and inexorable anger is not seemly for a king' (De clementia I. 5. 6) and this is a thought echoed by Diogo de Teive in his sentenças: 'Conselheira malíssima é a ira:/ Má certamente a todo homem é sempre/ Mas pior conselheira é ao príncipe' [Anger is a terrible advisor: it is always bad for everyone, but worse still for the prince]. ${ }^{41}$ Ferreira himself in a verse epstile to Simão da Silveira highlights the perils of anger: 'Ira a guerra pariu, ira armas gera/ ira chamou à boa razão fraqueza' [Anger spawned war, anger fathers arms, anger brings weakness to good reason]. ${ }^{42}$ In light of this, I think it is possible that Pedro - because he is angry and because he dismisses good counsel - could have been viewed as the worst

\footnotetext{
${ }^{39}$ See Earle, 'Tragedy at the Cross-Roads', pp. 314-5.

40 Stacey, p. 35.

41 Teive, p. 816.

${ }^{42}$ Ferreira, Carta 'a D. Simão da Silveira', Book II. 10. 52-4. See also Seneca's De ira in Seneca, Anger, Mercy, Revenge, ed. and trans. by Robert A. Kaster (Chicago: University of Chicago Press, 2010), pp. 3-13.
} 
character in the play by Ferreira and his early modern readers. Yet, Ferreira's play admits so many readings that it is difficult to be too assured in any single interpretation. Indeed, the play does offer two mitigating factors in defence (or, rather, in explanation) of Pedro's actions: the implacable force of love and the family history that sets a bad example for the young prince, suggesting that he belongs to one of those inescapably destructive dynasties that regularly feature in ancient and early modern drama. In the end, though, I think that appreciating the heat of Pedro's anger adds rather than takes away from the moral ambiguities of the play, because his anger only erupts at the end, once the Chorus have provided a whole series of arguments to excuse his behaviour.

Unlike in many Senecan imitations of the early modern period, Ferreira avoids adding a moralistic ending to Castro: Pedro declares his intentions unambiguously, but no punishment ensues in the play or, for that matter, in history, as Portuguese readers familiar with the historical events would be all too aware. ${ }^{43}$ No other character shines as a paragon of virtue, though. Let us not forget that even Inês has been involved with a married man...

So, what is cruelty? What is justice? What can or should a state do in the name of its selfpreservation? Castro offers no clear-cut answers. Rather, the play throws the meaning of key terms of moral evaluation into doubt. As I have shown, the counsellors, Pacheco and Coelho, have Seneca on their side when suggesting that Afonso kill Inês, so we need to rethink our assumptions about how 'evil' we take these characters to be. The excessive rhetoric of Pedro suggests that he is out of control and might have been considered the most terrifying character of them all by early modern audiences. Ultimately, though, Ferreira tangles the audience in a Gordian knot of conflicting emotions and moral perspectives. They are left with the difficult task of deciding what is cruel or just for themselves.

(7771 words)

${ }^{43}$ A. J. Boyle, Tragic Seneca: An Essay in the Theatrical Tradition (London: Routledge, 1997), pp. 183-4. 